Jurnal Media Pertanian Vol. 2 No. 1 Tahun 2017 Hal. 24 - 36

Media Komunikasi Hasil Penelitian dan Review Literatur Bidang Ilmu Agronomi ISSN $2503-1279$

\title{
TEKNOLOGI PRODUKSI DAN APLIKASI MIKROBA PELARUT HARA SEBAGAI PUPUK HAYATI
}

\author{
Ida Nursanti \\ Program Studi Agroteknologi, Fakultas Pertanian Universitas Batanghari \\ J1. Slamet Riyadi, Broni Jambi. 36122. Telp. +62074160103 \\ email: ida_unbari@yahoo.co.id
}

\begin{abstract}
The use of biological fertilizer can increase the amount of microorganisms and accelerates the process of mikrobologis, increase the availability of nutrient, nutrient absorption, pressed activate soil-borne disease, speed up the composting process, improve soil structure, and generate active substance that can increase the pertumbuhandan of development of the plant. Types of Microbes as biological fertilizer raw material among other bacteria and mushrooms or fungi. Solvent fospat bacteria is having bacteria consume simple carbon compounds, such as root exudate and the rest of the plant. Mycorrhiza fungi as the root of a plant helps to absorb the nutrient elements especially nutrient phosphate. Factors that determine the quality of biological fertilizer is the number of microorganisms. Storage at low temperature is generally more suited to survival of microorganisms, moisture, the death of the microorganism can be reduced. Microbes sensitive to direct sunlight. Production technology which has been successfully applied is engineering techniques and mikroenkapsulasi cell fermentation microbes. Biological fertilizer nutrient solvent products that have been produced; Biological fertilizer Enchancing Microbial Activities in The Soils, Sustainable, Bio-Tiens Golden Harvest, Plus Biological Fertilizer and Migra Bio-phosphate. Keywords: biodiversity, Fertilizer production technology.
\end{abstract}

\begin{abstract}
Abstrak
Penggunaan pupuk hayati dapat meningkatkan jumlah mikroorganisme dan mempercepat proses mikrobologis, meningkatkan ketersediaan hara, mengaktifkan serapan hara, menekan soil-borne disease, mempercepat proses pengomposan, memperbaiki struktur tanah, dan menghasilkan substansi aktif yang dapat meningkatkan pertumbuhandan perkembangan tanaman. Jenis Mikroba sebagai bahan dasar pupuk hayati antara lain bakteri dan cendawan atau fungi. Bakteri pelarut fospat merupakan bakteri dekomposer yang mengkonsumsi senyawa karbon sederhana, seperti eksudat akar dan sisa tanaman. Mikoriza sebagai jamur akar membantu tanaman untuk menyerap unsur hara terutama unsur hara fosfat. Faktor yang menentukan mutu pupuk hayati adalah jumlah mikroorganisme. Penyimpanan pada suhu rendah umumnya lebih cocok untuk ketahanan hidup mikroorganisme, mempertahankan kelembaban, kematian mikroorganisme dapat dikurangi. Mikroba peka terhadap sinar matahari langsung. Teknologi produksi yang telah berhasil diterapkan adalah rekayasa fermentasi dan teknik mikroenkapsulasi sel mikroba. Produk pupuk hayati pelarut hara yang telah dihasilkan ; Pupuk Hayati Enchancing Microbial Activities in The Soils, BioLestari, Tiens Golden Harvest, Migra Plus dan Pupuk Hayati Bio-fosfat.
\end{abstract}

Kata kunci : Pupuk hayati, teknologi produksi. 
Jurnal Media Pertanian Vol. 2 No. 1 Tahun 2017 Hal. 24 - 36

Media Komunikasi Hasil Penelitian dan Review Literatur Bidang Ilmu Agronomi ISSN $2503-1279$

\section{PENDAHULUAN}

Pupuk hayati atau lebih dikenal dengan nama pupuk mikroba telah banyak beredar di pasaran dan beberapa daerah mulai digunakan oleh petani. Pupuk mikroba digolongkan kedalam kelompok pupuk alternatif. Secara umum istilah pupuk hayati diartikan sebagai suatu bahan yang mengandung sel hidup atau dalam keadaan laten dari suatu strain penambat nitrogen, pelarut, atau mikroorganisme selulolitik yang diberikan ke biji, tanah, atau ketempat pengomposan.

Pupuk hayati banyak dimanfaatkan petani untuk meningkatkan hasil dan memperbaiki mutu. Namun, pemakaian pupuk tersebut harus hati-hati karena komposisi hara yang ada pada label kemasan kadang tidak sesuai dengan yang dikandungnya. Penggunaan pupuk hayati bertujuan untuk meningkatkan jumlah mikroorganisme dan mempercepat proses mikrobologis untuk meningkatkan ketersediaan hara, sehingga dapat dimanfaatkan oleh tanaman. Pupuk mikroba bermanfaat untuk mengaktifkan serapan hara oleh tanaman, menekan soil-borne disease (kerusakan tanah), mempercepat proses pengomposan, memperbaiki struktur tanah, dan menghasilkan substansi aktif yang dapat meningkatkan pertumbuhandan perkembangan tanaman.

Di Indonesia, mikroorganisme telah lama dimanfaatkan, terutama pada proses fermentasi makanan secara tradisional, dan juga pada minuman. Adanya keputusan pemerintah untuk memberi prioritas yang tinggi pada pengembangan bioteknologi, menyebabkan perhatian pada penggunaan mikroorganisme makin meningkat, selain digunakan dalam proses fermentasi secara tradisional. Bentuk-bentuk inokulan pupuk mikroba yang biasa digunakan adalah biakan agar, biakan cair, biakan kering, biakan kering beku, dan tepung. Inokulan yang digunakan secara luas di lapangan adalah yang berbentuk biakan cair dan tepung. Untuk memudahkan aplikasi dilapangan diperlukan bahan pembawa (carrier). Sebagai bahan pembawa inokulan tepung, dapat digunakan bahan organik seperti gambut, arang, sekam, dan kompos. Untuk bahan pembawa anorganik digunakan bentonit, vermikulit, atau zeolit. Petani menggunakan pupuk mikroba dengan harapan dapat meningkatkan hasil dan mutu tanaman pada tingkat biaya yang rendah melalui penghematan tenaga kerja dan pupuk kimia. Namun, sering dijumpai bahwa pupuk mikroba yang dijual tidak menunjukan sifat mikrobiologis, artinya mikroorganisme yang terdapat dalam prduk tersebut tidak dapat diidentifikasi dan komposisinya tidak sesuai dengan yang tertera pada label kemasan. Banyak produk tersebut diiklankan seolah-olah dapat menyelesaikan semua masalah yang dihadapi petani (Rahmawati, 2005).

\section{BAKTERI PELARUT HARA}

Mikroba yang berperanan dalam pelarutan fospat antara lain bakteri, antara lain: Bacillus firmus, B. subtilis, B. cereus, B. licheniformis, B. polymixa, B. megatherium, Arthrobacter, Pseudomonas, Achromobacter, Flavobacterium, Micrococus dan Mycobacterium. Pseudomonas merupakan salah satu genus dari Famili Pseudomonadaceae.

Bakteri ini adalah bakteri aerob khemoorganotrof ,berbentuk batang lurus atau lengkung, ukuran tiap sel bakteri 0.5-0.1 $1 \mu \mathrm{m} \times 1.5-4.0 \mu \mathrm{m}$, tidak membentuk spora dan bereaksi negatif terhadap pewarnaan Gram.Di dalam tanah jumlahnya 3-15\% dari populasi 
Jurnal Media Pertanian Vol. 2 No. 1 Tahun 2017 Hal. 24 - 36

Media Komunikasi Hasil Penelitian dan Review Literatur Bidang Ilmu Agronomi ISSN $2503-1279$

bakteri. Pseudomonas terbagi atas grup, diantaranya adalah sub-grup berpendarfluor (Fluorescent) yang dapat mengeluarkan pigmen phenazine. Kebolehan menghasilkan pigmen phenazine juga dijumpai pada kelompok tak berpendarfluor yang disebut sebagai spesies Pseudomonas multivorans. Sehubungan itu maka ada empat spesies dalam kelompok Fluorescent yaitu Pseudomonas aeruginosa, P. fluorescent, P. putida, dan P. multivorans (Hasanudin, 2003).

Bakteri pelarut fospat merupakan bakteri decomposer yang mengkonsumsi senyawa carbon sederhana, seperti eksudat akar dan sisa tanaman. Melalui proses ini bakteri mengkonversi energi dalam bahan organik tanah menjadi bentuk yang bermanfaat untuk organisme tanah lain dalam rantai makanan tanah. Bakteri ini dapat merombak pemcemar tanah, dapat menahan unsur hara di dalam selnya. Aktivitas bakteri pelarut posfat akan tinggi pada suhu $30^{\circ} \mathrm{C}-40^{\circ} \mathrm{C}$ (bakteri mesophiles), kadar garam tanah $<0,85 \%$ dengan kondisi aerasi tanah baik dan reaksi tanah yang mendukung aktivitas bakteri ini adalah pada pH 4-5 (Handayanto dan Hairiyah, 2007).

Bakteri pelarut fosfat Pseudomon putida maupun $P$. aeruginosa terbukti telah

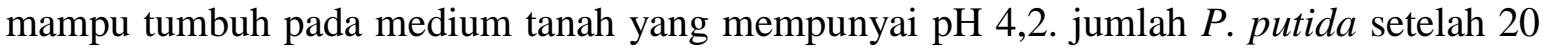
hingga 40 hari setelah penanaman adalah $5-6$ x $106 \mathrm{CFU} / \mathrm{g}$ akar. Sedangkan jumlah $P$. aeruginosa/g tanah setelah akhir pengamatan lebih rendah jika dibandingkan dengan jumlah koloni $P$. putida . beberapa spesies dari Pseudomonas sp mempunyai kemampuan yang rendah untuk tumbuh pada kondisi asam ( $\mathrm{pH}$ dibawah 4,5).

Struktur bakteri terbagi menjadi dua yaitu: (1) Struktur dasar (dimiliki oleh hampir semua jenis bakteri) Meliputi: dinding sel, membran plasma, sitoplasma, ribosom, DNA, dan granula penyimpanan (2) Struktur tambahan (dimiliki oleh jenis bakteri tertentu) Meliputi kapsul, flagelum, pilus, fimbria, klorosom, Vakuola gas dan endospora. Struktur dasar bakteri : (1) Dinding sel tersusun dari peptidoglikan yaitu gabungan protein dan polisakarida (ketebalan peptidoglikan membagi bakteri menjadi bakteri gram positif bila peptidoglikannya tebal dan bakteri gram negatif bila peptidoglikannya tipis) (2) Membran plasma adalah membran yang menyelubungi sitoplasma tersusun atas lapisan fosfolipid dan protein (3) Sitoplasma adalah cairan sel (4) Ribosom adalah organel yang tersebar dalam sitoplasma, tersusun atas protein dan RNA (5) Granula penyimpanan, karena bakteri menyimpan cadangan makanan yang dibutuhkan (Elfiati, 2005).

\section{MIKORIZA PELARUT HARA}

Fungi yang berperan dalam pelarut hara adalah jenis mikoriza. Mikoriza yang banyak berasosiasi dengan tanaman adalah jenis Glomus fasciculatus, Glomus tenue, Glomus clarum, Glomus invermaium, Paraglomus sp, Sclerocystis reticulata, Acaulospora sp, Entrophospora sp, Gigaspora sp,Thelophora amariana,Laccaria laccata, Lactarius sanguifluus, Cenococcum spp, Piloderma bicolor, Hysterangium separabile. Jenis Ektomikoriza : Thelopora amaliana, Laccaria laccata, Lactarius sanguifluus, Cenococum ssp, Piloderma bicolor, Hysterangium separabile.

Mikoriza dikenal dengan jamur tanah karena habitatnya berada di dalam tanah dan berada di area perakaran tanaman (rizosfer). Selain disebut sebagai jamur tanah juga biasa dikatakan sebagai jamur akar. Keistimewaan dari jamur ini adalah kemampuannya dalam 
Jurnal Media Pertanian Vol. 2 No. 1 Tahun 2017 Hal. 24 - 36

Media Komunikasi Hasil Penelitian dan Review Literatur Bidang Ilmu Agronomi ISSN $2503-1279$

membantu tanaman untuk menyerap unsur hara terutama unsur hara Phosphates (P) Mikoriza merupakan suatu bentuk hubungan simbiosis mutualistik antar cendawan dengan akar tanaman. Baik cendawan maupun tanaman sama-sama memperoleh keuntungan dari asosiasi ini. infeksi ini antara lain berupa pengambilan unsur hara dan adaptasi tanaman yang lebih baik. Dilain pihak, cendawan pun dapat memenuhi keperluan hidupnya (karbohidrat dan keperluan tumbuh lainnya) dari tanaman inang (Handayanto dan Hairiyah, 2007).

Berdasarkan struktur dan cara cendawan menginfeksi akar, mikoriza dapat dikelompokkam ke dalam tiga tipe : Ektomikoriza, Ektendomikoriza dan Endomikoriza. Ektomikoriza mempunyai sifat antara lain akar yang kena infeksi membesar, bercabang, rambut-rambut akar tidak ada, hifa menjorok ke luar dan berfungsi sebagi alat yang efektif dalam menyerap unsur hara dan air, hifa tidak masuk ke dalam sel tetapi hanya berkembang diantara dinding-dinding sel jaringan korteks membentuk struktur seperrti pada jaringan Hartiq. Ektendomikoriza merupakan bentuk antara (intermediet) kedua mikoriza yang lain. Ciri-cirinya antara lain adanya selubung akar yang tipis, hifa dapat menginfeksi dinding sel korteks dan juga sel-sel korteknya. Penyebarannya terbatas dalam tanah-tanah hutan sehingga pengetahuan tentang mikoriza ini sangat terbatas. Endomikoriza mempunyai sifatsifat antar lain akar yang kena infeksi tidak membesar, lapisan hifa pada permukaan akar tipis, hifa masuk ke dalam individu sel jaringan korteks, adanya bentukan khusus yang berbentuk oval yang disebut Vasiculae (vesikel) dan sistem percabangan hifa yang dichotomous disebut arbuscules (arbuskul) .

Cendawan Mikoriza Arbuskula (CMA) membentuk organ-organ khusus dan mempunyai perakaran yang spesifik. Organ khusus tersebut adalah arbuskul (arbuscule), vesikel (vesicle) dan spora. Vesikel merupakan struktur cendawan yang berasal dari pembengkalan hifa internal secara terminal dan interkalar, kebanyakan berbentuk bulat telur, dan berisi banyak senyawa lemak sehingga merupakan organ penyimpanan cadangan makanan dan pada kondisi tertentu dapat berperan sebagai spora atau alat untuk mempertahankan kehidupan cendawan. Arbuskula merupakan hifa bercabang halus yang dibentuk oleh percabangan dikotomi yang berulang-ulang sehingga menyerupai pohon dari dalam sel inang. Arbuskul merupakan percabangan dari hifa masuk kedalam sel tanaman inang. Masuknya hara ini ke dalam sel tanaman inang diikuti oleh peningkatan sitoplasma, pembentukan organ baru, pembengkokan inti sel, peningkatan respirasi dan aktivitas enzim (Kartika, 2006).

Spora terbentuk pada ujung hifa eksternal. Spora ini dapat dibentuk secara tunggal, berkelompok atau di dalam sporokarp tergantung pada jenis cendawannya. Perkecambahan spora sangat sensitif tergantung kandungan logam berat di dalam tanah dan juga kandungan Al. kandungan Mn juga mempengaruhi pertumbuhan miselium. Spora dapat hidup di dalam tanah beberapa bulan sampai sekarang beberapa tahun. Namun untuk perkembangan CMA memerlukan tanaman inang. Spora dapat disimpan dalam waktu yang lama sebelum digunakan lagi. Banyak faktor biotik dan abiotik yaang menentukan perkembangan CMA. Faktor-faktor tersebut antar lain suhu, tanah, kadar air tanah, pH, bahan organik tanah, intensitas cahaya dan ketersediaan hara, logam berat dan fungisida (Handayanto dan Hairiyah, 2007). 
Jurnal Media Pertanian Vol. 2 No. 1 Tahun 2017 Hal. 24 - 36

Media Komunikasi Hasil Penelitian dan Review Literatur Bidang Ilmu Agronomi ISSN $2503-1279$

Suhu yang tinggi pada siang hari $\left(35^{\circ} \mathrm{C}\right)$ tidak menghambat perkembangan akar dan aktivitas fisiologi CMA. Peran mikoriza hanya menurun pada suhu diatas 40 0C. suhu bukan merupakan faktor pembatas utama bagi aktivitas CMA. Suhu yang sangat tingi lebih berpengaruh terhadap pertumbuhan tanaman inang. Untuk tanaman yang tumbuh di daerah kering, adanya CMA menguntungkan karena dapat meningkatkaan kemampuan tanaman untuk tumbuh dan bertahan pada kondisi yang kurang air. Adanya CMA dapat memperbaiki dan meningkatkan kapasitas serapan air tanaman inang. Cendawan pada umunya lebih tahan terhadap perubahan $\mathrm{pH}$ tanah. Meskipun demikian daya adaptasi masing-masing spesies cendawan CMA terhadap $\mathrm{pH}$ tanah berbeda-beda karena $\mathrm{pH}$ tanah mempengaruhi perkecambahan, perkembangan dan peran mikoriza terhadap pertumbuhan tanaman. (Rao, 2004).

Bahan organik merupakan salah satu komponen penyusun tanah yang penting disamping bahan anorganik, air dan udara. Jumlah spora CMA tampaknya berhubungan erat dengan kandungan bahan organik di dalam tanah. Jumlah maksimum spora ditemukan pada tanah-tanah yang mengandung bahan organik 1-2 persen sedangkan paada tanah-tanah berbahan organik kurang dari 0.5 persen kandungan spora sangat rendah. Intensitas cahaya yang tinggi dengan kekahatan nitrogen ataupun fospor sedang akan meningkatkan jumlah karbohidrat didalam akar sehingga membuat tanaman lebih peka terhadap infeksi oleh cendawaan CMA. Derajat infeksi terbesar terjadi pada tanah-tanah yang mempunyai kesuburan yang rendah. Pertumbuhan perakaran yang sangat aktif jarang terinfeksi oleh CMA. Jika pertumbuhan dan perkembangan akar menurun infeksi CMA meningkat.

Beberapa spesies CMA diketahui mampu beradaptasi dengan tanah yang tercemar seng (Zn), tetapi sebagian besar spesies CMA peka terhadap kandungan $\mathrm{Zn}$ yang tinggi. Pada beberapa penelitian lain diketahui pula bahwa strain-strain cendawan CMA tertentu toleran terhadap kandungan $\mathrm{Mn}, \mathrm{Al}$, dan $\mathrm{Na}$ yang tinggi. Fungisida Agrosan, Benlate, Plantavax, meskipun dalam konsentrasi yang sangat rendah $(2,5 \mathrm{mg}$ per $\mathrm{g}$ tanah) menyebabkan turunnya kolonisasi CMA yang mengakibatkan terhambatnya pertumbuhan tanaman dan pengambilan P (Madjid, 2009).

\section{TEKNIK IDENTIFIKASI PUPUK HAYATI MIKROBA PELARUT HARA}

Identifikasi mikroba sangat diperlukan untuk menentukan atau mengetahui jenis bakteri yang diinginkan. Teknik identifikasi populasi mikroba dapat dilakukan dengan metode tidak langsung, yaitu berdasarkan jumlah koloni pada media yeast mannitol agar (YMA) + congored ataupun YMA + bromthymol blue (BTB). Bahan dan alat yang diperlukan adalah penangas air, mortir penumbuk steril, neraca, pipet steril, air steril, lampu bunsen,contoh tanah, petridish dan mikroskop.

Selanjutnya menurut Madjid (2009) pengambilan contoh tanah dilakukan dengan cara pengamatan tanah di lapangan untuk mengetahui morfologi, klasifikasi dan penyebarannya. Pengamatan dapat dilakukan dengan sistem grade dengan jarak 250x250m atau disesuaikan dengan perubahan landscape. Selain contoh tanah profil diambil juga contoh tanah komposit pada kedalaman $0-50 \mathrm{~cm}$. Contoh tanah komposit merupakan campuran homogen dari beberapa tempat pengambilan dari satuan lahan yang sama, setelah 
Jurnal Media Pertanian Vol. 2 No. 1 Tahun 2017 Hal. 24 - 36

Media Komunikasi Hasil Penelitian dan Review Literatur Bidang Ilmu Agronomi ISSN $2503-1279$

diaduk rata kemudian diambil 500gr. Tanah diupayakan dalam keadaan lembab untuk keperluan analisis di laboratorium.

Prosedur identifikasi dapat dilakukan dengan cara sebagai berikut :

1. Pada bagian petridish diberi tanda sesuai dengan tingkat pengenceran yaitu $10^{-1}, 10^{-2}$, $10^{-3}$ dan seterusnya.

2. Sebanyak $1 \mathrm{gr}$ contoh tanah ditumbuk dalam mortir steril kemudian dimasukkan secara aseptik bersama $9 \mathrm{cc}$ air steril ke dalam erlenmeyer (pengenceran $10^{-2}$ ), selanjutnya dikocok dengan hati-hati sampai homogen.

3. Inokulasi secara aseptik 1cc masing-masing contoh tanah yang telah homogen ke dalam petridish steril dan tabung gelas yang berisi $9 \mathrm{cc}$ air steril (pengenceran $10^{-3}$ ) kemudian kocok dilakukan seperti no 2 .

4. Media YMA+congored atau BTB steril yang telah diencerkan pada suhu lebih krang $50^{\circ} \mathrm{C}$ dituangkan secara aseptik ke dalam masing-masing petridish yang telah diinokulasi, kemudian digoyang-goyang secukupnya dan biarkan sampai membeku.

5. Inokulasi pada suhu $28^{0} \mathrm{C}$ selama 8 hari dengan posisi petridish terbalik.

6. Populasi koloni dihitung pada umur 4 hari dan 8 hari dengan menggunakan mikroskop pembesaran 1000 kali.

\section{TEKNOLOGI PRODUKSI DAN APLIKASI PUPUK HAYATI MIKROBA PELARUT HARA}

Salah satu faktor yang menentukan mutu pupuk mikroba adalah jumlah mikroorganisme yang terkandung didalamnya. Jumlah tersebut dapat berkurang karena suhu yang tinggi. Hasil penelitian menunjukan bahwa penyimpanan pada suhu rendah umumnya lebih cocok untuk ketahanan hidup mikroorganisme daripada suhu tinggi. Peningkatan suhu menyebabkan kelembaban menurun. Dengan mempertahankan kelembaban, kematian mikroorganisme dapat dikurangi. Berdasarkan tingkat kelembabannya yang cukup tinggi, gambut cukup baik untuk pertumbuhan mikroorganisme, baik berupa bakteri maupun jamur. Selain peka terhadap suhu tinggi mikroba juga peka terhadap sinar matahari langsung.

Pada penggunaan inokulan bakteri Rhizobium, inokulasi biji legum harus dilakukan pada tempat yang teduh, karena bakteri tersebut tidak tahan terhadap sinar matahari langsung. Untuk melindungi konsumen dan produsen pupuk mikroba, maka diperlukan suatu sistem pengawasan yang memadai dan dapat dipertanggungjawabkan, sehingga halhal yang tidak diinginkan seperti pemalsuan atau penurunan kualitas dapat dihindari. Sistem monitorig dapat dilakukan untuk mengetahui jumlah, jenis, dan kualitas pupuk mikroba yang beredar di pasaran. Pada pengujian pupuk mikroba, perlu diamati label pada kemasan yang mencantumkan nama genus serta jumlah mikroorganisme, tanggal kadaluwarsa, cara penyimpanan, seta jenis tanaman yang cocok.

Syarat jumlah populasi mikroorganisme yang terkandung dalam suatu produk berbeda untuk tiap negara. Australia mensyaratkan sekitar 107-108 sel $\mathrm{g}^{-1}$ dengan batas kadaluwarsa 2 bulan, Afrika Utara dan Taiwan mensyaratkan sekitar 108 sel g$^{-1}$. Di Indonesia, sampai saat ini baku mutu atas pupuk mikroba yang beredar baru untuk inokulan Rhizobium, sedangkan untuk jenis pupuk mikroba lainnya belum ada (Rao, 2004). 
Jurnal Media Pertanian Vol. 2 No. 1 Tahun 2017 Hal. 24 - 36

Media Komunikasi Hasil Penelitian dan Review Literatur Bidang Ilmu Agronomi ISSN $2503-1279$

Fosfor memegang peran penting dalam transportasi energi untuk pertumbuhan dan perkembangan tanaman. Sebagian Besar fosfat dalam tanah tidak dapat dimanfaatkan oleh tanaman. Sekitar 90\% fosfat dalam tanah terleh tanaman dan 2 hingga 6 minggu setelah pemupukan, $80 \%$ dari fosfat yang diaplikasikan juga akan terikat dan tidak dapat dimananfaatkan. Tanaman menyumbang hasil sampingnya untuk makanan mikroba. Mikroba membantu tanaman mencerna hara lebih banyak, sehingga tanaman berkembang lebih kuat dan sistem perakaran lebih luas.

Pemanfaatan mikroba pelarut fosfat merupakan salah satu alternatif untuk memecahkan masalah dalam meningkatkan efisiensi pemupukan. Mekanisme pelarutan fosfat dari bahan yang sukar larut oleh aktivitas mikroba pelarut fosfat banyak dikaitkan dengan kemampuan mikroba yang bersangkutan dalam menghasilkan enzim fosfatase, Stase, dan asam organik hasil metabolisme seperti asetat. Propionat, glikolat, fumarat, oksalat, suksinat, lartrat, sitrat, laktat, dan ketoglutarat. Proses utama pelarutan senyawa fosfat sukar larut karena adanya produksi asam organik dan sebagian asam anorganik oleh mikroba yang dapat berinteraksi dengan senyawa fosfat sukar larut serta melarutkan fosfat dari kompleks Al, Fe, Mn, dan Ca (Elfiati, 2005).

Peningkatan efisiensi fosfat juga berarti suatu kesempatan aplikasi antara lain BioPhos mengandung lebih dari satu fungsi kelompok mikroba, yaitu mikroba pelarut fosfat, mikoriza. dan senyawa organik alami pemacu pertumbuhan tanaman. Teknologi ini tidak hanya terhadap peningkatan basil tanaman, tetapi juga peningkatan efisiensi pemupukan $\mathrm{P}$, dan babkan meningkatkan keamanan terhadap aplikasi hara lainnya, dengan kala lain meningkatkan kesuburan Hasil Penelitian BioPhos merupakan campuran mikroba efek Micrococcus spp. Grt 3, Aspergillus niger NHJ2, dan mikoriza Glomus yang dilengkapi dengan formulasi bahan pembawa yang sesuai.

Menurut Gunalan (2006) bahwa teknik bioteknologi telah berhasil diterapkan dalam teknologi produksinya, yaitu rekayasa fermentasi dan teknik mikroenkapsulasi sel mikroba untuk menjamin peningkatan populasi mikroba dan menekan kontaminasi dari mikroba yang tidak dikehendaki selama penyimpanan dan transportasi. Serta meningkatkan ketahanan hidup mikroba tanpa mempengaruhi keefektifannya. Pemanfaatan BioPhos di tanah masam-Al atau tanah sawah jenuh fosfat dapat meningkatkan ketersediaan fosfat baik dari fosfat yang diaplikasikan maupun dari dalam tanah. serta akan meningkatkan serapan fosfat tanaman dan hasilnya. Fungi pelarut fosfat terpilih mampu meningkatkan pelarutan fosfat hingga $245 \mathrm{kali}$ dari kontrol (tanpa inokulasi) 0,60 ug/ml (pH 4.65) hingga 147,28 ug $\mathrm{rnl}^{-1}(\mathrm{pH} 2.9)$ dan bakteri pelarut fosfat 154 kali dari kontrol 2,56 ug/ml (pH 6,47) hingga $394,85 \mathrm{ug} / \mathrm{ml}(\mathrm{pH} \mathrm{5,1)}$.

Aplikasi produk Biophos pada kedelai yang dipupuk dengan $50 \mathrm{~kg} \mathrm{P} / \mathrm{ha}$ meningkatkan tingkat infeksi mikoba hingga 171,78\% dibandingkan dengan aplikasi 100 $\mathrm{kg} \mathrm{P} / \mathrm{ha}(23,59 \%)$. Interaksi antara Biophos dengan pupuk P, $50 \mathrm{~kg}$ meningkatkan serap 100 $\mathrm{kg}$ P. Aplikasi BioPhos pada kedelai di tanah hingga 60\%. Aplikasi BioPhos pada kentang, jagung dan padi (200 g per $20 \mathrm{~kg}$ benih menurunkan penggunaan pupuk NPK yang direkomendasikan hingga 75\%. Demonstrasi plot aplikasi BioPhos pada kedelai dan padi di 12 lokasi transmigran di Lámbale, Sulawesi Selatan dengan kombinasi pemupukan 100 $\mathrm{kg} / \mathrm{ha}$ urea, $50 \mathrm{~kg} / \mathrm{ha} \mathrm{SP} 36$. dan $50 \mathrm{~kg} / \mathrm{ha} \mathrm{KCl}$ meningkatkan hasil kedelai . 
Jurnal Media Pertanian Vol. 2 No. 1 Tahun 2017 Hal. 24 - 36

Media Komunikasi Hasil Penelitian dan Review Literatur Bidang Ilmu Agronomi ISSN $2503-1279$

Aplikasi Biophos dengan kombinasi dosis pemupukan meningkatkan hasil kedelai sebesar 28,32\% dan 16\% pada padi. Bahkan aplikasi Biophos pada padi tanpa pemupukan dapat meningkatkan hasil hingga 43\% Nilai Tambah Teknologi Biophost merupakan pupuk mikroba pelarut fosfat yang dapat mensubstitusi sebagian pupuk yang dibutuhkan oleh tanaman melalui kemampuannya melarutkan fosfat yang sukar larut menjadi tersedia bagi tanaman. Sehingga dapat rnenghemat penggunaan pupuk kimia. Hanya separuh dari dosis pupuk kimia yang dibutuhkan, bahkan aplikasi BioPhos juga dapat meningkatkan efisiensi pemupukan $\mathrm{N}$ dan $\mathrm{K}$. Petani akan dapat menikmati penurunan biaya pemupukan dan kenaikan hasil produksi. Jamur Aspergilus niger dapat dipeletkan bersama dengan serbuk batuan fosfat dan bahan organik membentuk pupuk batuan fosfat yang telah mengandung jasad pelarut fosfat. Aspergillus niger tersebut dapat bertahan hidup setelah masa simpan 90 hari dalam bentuk pelet.

Mikroba pelarut fosfat (MPF) umumnya diisolasi dari contoh tanah. MPF yang umum didapatkan antara lain dari kelompok fungi, bakteri, dan actinomicetes. Prosedur umum untuk mengisolasi MFP adalah sebagai berikut:(1) Satu gram contoh tanah dimasukkan ke dalam $99 \mathrm{ml}$ larutan garam fisiologis $(0.85 \% \mathrm{NaCl})$ steril dan dikocok selama 24 jam atau semalam. Dari pengenceran ini diperoleh seri pengenceran 10 ext- 2 . Tujuan pengocokan ini agar diperoleh lebih banyak isolat,khususnya isolat fungi. (2) Satu ml larutan dari pengenceran 10 ext. -2 ditambahkan ke dalam 99 ml larutan garam fisiologis dan dikocok/diaduk hingga tercampur merata. Langkah ini diperoleh pengenceran 10 ext. -4. Pengenceran terus dilakukan hingga seri pengencera 10 ext. -6 s/d 10 ext. -8 . (3) Buat medium agar Pikovskaya. (4). Satu ml dari setiap seri pengenceran yang telah dibuat dimasukkan ke dalam cawan petri steril. Medium agar Pikovskaya yang masih cair (suhu kurang lebih 50oC) dituangkan ke dalam cawan. Cawan digoyang agar sample dan media tercampur merata. (5). Ulangi langkah di atas secukupnya. (6) Inkubasi dalam posisi terbalik selama beberapa hari.(7) Mikroba yang dapat melarutkan fosfat akan membentuk zona bening di dalam medium Pikovskaya.(8) Setelah diperoleh MPF segera dipisahkan dan dimurnikan di dalam medium Pikovskaya yang lain.

Isolat bakteri dan actinomicetes biasanya segera tumbuh pada umur $2-3$ hari, sedangkan fungi baru mulai tumbuh setelah $1-2$ minggu. Biasanya menggunakan antibiotik (antibakteri) apabila akan mengisolasi fungi. Tanpa antifungi fungi pelarut fosfat sulit diperoleh. Fungi umumnya kalah cepat tumbuhnya dengan bakteri, sehingga pertumbuhannya terhambat oleh bakteri. Indek pelarutan fosfat ini berdasarkan pada metode yang dijelaskan oleh Premono, Moawad, dan Vlek (1996). Secara aseptis 1 ose (untuk bakteri) atau satu cuplikan kecil dengan diameter $8 \mathrm{~mm}$ untuk fungi diinokulasikan ke atas media Pikovskaya. Setiap perlakuan dilakukan dengan beberapa ulangan, minimal duplo. Isolat diinkubasi selama beberapa hari. Indeks pelarutan fosfat adalah perbandingan antara diameter zona jernih dibagi dengan diameter koloni. Indek pelarutan fosfat sesuai digunakan untuk screening awal mikroba pelarut fosfat. Metode ini mudah dan murah untuk dilakukan (Rao, 2004). Selanjutnya dijelaskan pula bahwa metoda atau cara produksi inokulum mikoriza dan aplikasi secara langsung di lahan atau on farm production adalah sebagai berikut : 
Jurnal Media Pertanian Vol. 2 No. 1 Tahun 2017 Hal. 24 - 36

Media Komunikasi Hasil Penelitian dan Review Literatur Bidang Ilmu Agronomi ISSN $2503-1279$

1. Persiapan Lahan

Diperlukan bedengan berukuran $25 \mathrm{~m} 2$ untuk menghasilkan $4000 \mathrm{~kg}$ inokulum berupa campuran tanah, spora dan akar terinfeksi. Sebaiknya dipilih lahan yang kurang subur yang dekat dengan areal penanaman.

2. Sterilisasi Lahan

Pada lahan di atas disebarkan 50-60 g dazomet granular per m2, diaduk merata, lalu disiram air untuk melarutkan butiran dazomet dan ditutup plastik. Perlakukan berikutnya adalah pencangkulan, selain untuk meratakan hasil, juga untuk menguapkan sisa fumigasi.Lima hari kemudian, bedeng tersebut dapat digunakan.

3. Inokulasi

Pada tiap lubang yang dibuat, diberikan starter inokulumdari jenis cendawan mikoriza yang akan dikembang biakkan. Tanaman inang dapat berupa jagung, sorgum atau pueraria. Untuk menjamin terjadinya infeksi pada media pengecambahan dapat diberi inokulum sebagai perlakuan pra-inokulasi sebelum ditanam di bedeng perbanyakan.

3. Multiplikasi

Perawatan tanaman perlu dilakukan selama pertumbuhan tanaman di lahan atau bedeng pembiakan. Setelah tanaman inang keluar bunga (jantan atau betina) sebaiknya digunting agar tanaman dapat merangsang terbentuknya spora cendawan mikoriza di lahan tersebut.

4. Panen Inokulum

Setelah tanaman inang mengering, tanah bedeng tersebut sudah dapat digunakan sebagai inokulum. Pengambilan tanah sebagai inokulum dilakukan hingga kedalaman sebatas lapisan olah yang telah dilakukan sebelumnya $(20-30 \mathrm{~cm})$.

5. Pemakaian hasil

Hasil panen dapat langsung diaplikasikan pada tanaman ubi kayu dengan dosis $200 \mathrm{~g}$ per tanaman. Stek ubi kayu ditanamkan pada lubang tersebut tepat diatas permukaan inokulum yang diberikan.

\section{PRODUK PUPUK HAYATI PELARUT HARA}

A. Pupuk Hayati EMAS (Enchancing Microbial Activities in The Soils)

Salah satu jenis pupuk hayati adalah pupuk hayati EMAS (Enchancing Microbial Activities in The Soils) atau PHE. PHE mengandung mikroba sebagai bahan aktif yang mempunyai peranan tersendiri yaitu : Azospirillum lipoverum berupa bakteri penambat $\mathrm{N}$ bebas ; Azotobacter beijerinckii bakteri pemantap agregat dan penambat N-bebas, Aeromonas punctata sebagai bakteri pemantap agregat dan Aspergillus niger berupa fungi pelarut fosfat. Enchancing Microbial Activities in The Soils (EMAS) adalah pupuk hayati (biofertilezer) berbahan aktif bakteri penambat $\mathrm{N}$-bebas tanpa bersimbiosis dengan tanaman, mikroba pelarut fosfat dan kalium serta pemantap agregat tanah. Keunggulan PHE dari pupuk hayati lainnya yaitu mampu meningkatkan efisiensi penggunaan pupuk anorganik melalui penurunan dosis.

Diintroduksinya jenis mikroba dalam PHE ke dalam tanah diharapkan berlangsung optimal. Produk PHE dihasilkan dalam bentuk granul (butiran) berwarna putih keabuan dengan diameter 2-3 mm melalui proses granulasi. Mikroba sebagai bahan aktif tetap 
Jurnal Media Pertanian Vol. 2 No. 1 Tahun 2017 Hal. 24 - 36

Media Komunikasi Hasil Penelitian dan Review Literatur Bidang Ilmu Agronomi ISSN $2503-1279$

efektif sampai masa simpan 12 bulan .PHE dirancang untuk membantu penyediaan unsur hara yang terikat kuat di dalam tanah.

B. Bio-Lestari

Formula Bio-Lestari diramu khusus untuk penyuburan lahan pertanian. Mikroba penyubur Bio-Lestari mampu meningkatkan kemampuan nodulasi tanaman kacangkacangan, ketersediaan hara di dalam tanah, dan menaikkan efisiensi pemakaian pupuk. Bio-Lestari merupakan campuran bakteri pembentuk nodul pada tanaman kacangkacangan, penambat nitrogen bebas, dan cendawan pelarut hara dengan formulasi bahan pembawa yang mengandung senyawa organik alami pemacu tumbuh dan unsur mikro yang diperlukan oleh mikroba dan tanaman.

Perhatian dari penggunaan pupuk bio-lestari ini adalah Jangan tercampur dengan pupuk kimia, pada lahan masam diperlukan pengapuran secukupnya sampai pH 5,5, simpan Bio-Lestari di bawah suhu $<20^{\circ} \mathrm{C}$ dan jauh dari sinar, jangan digunakan lagi bila melebihi masa kadaluwarsa.

C. Pupuk Hayati Bio-fosfat

Biofertilizer/Penggunaan pupuk mikroba pelarut fosfat dan mikoriza bertujuan untuk menghindari masalah rendahnya $\mathrm{P}$ tersedia di lahan sawah dan lahan masam. Mikroba pelarut $\mathrm{P}$ maupun melarutkan $\mathrm{P}$ yang tidak tersedia dengan mengeluarkan asam organik, dan mikoriza berfungsi sebagai fasilitator penyerapan P. Telah dikembangkan pupuk mikroba pelarut fosfat yang disebut "Bio-Fosfat" yang dapat meningkatkan efisiensi pemupukan sampai 50 persen (dari rekomendasi pemupukan $\mathrm{P} 100 \mathrm{~kg} / \mathrm{ha}$ menjadi 50 $\mathrm{kg} / \mathrm{ha}$ ). Dua penelitian telah dilaksanakan di Laboratorium Mikrobiologi dan di Rumah Kaca Balitbio Bogor. Penelitian pendahuluan dilaksanakan pada bulan Januari 1995 sampai Juli 1995. Digunakan rancangan acak lengkap dengan tiga ulangan. Sebagai perlakuan adalah: (1) inokulasi Rhizobium japonicum, (2) inokulasi R. japonicum dan fungi pelarut fosfat Aspergillus niger, (3) inokulasi R. japonicum dan mikoriza Gigaspora margarita; (4) inokulasi R. japonicum, A. niger, dan G. margarita.

Hasil penelitian menunjukkan bahwa inokulasi fungi pelarut fosfat dicampur dengan mikoriza meningkatkan pertumbuhan kedelai, aktivitas penambatan $\mathrm{N}$, dan serapan $\mathrm{N}$ dan $\mathrm{P}$ berturut-turut 7,8 kali, 1,3 kali, 8 kali, dan 10 kali. Tidak ada perbedaan yang nyata antara perlakuan P $50 \mathrm{~kg}$ P205/ha dengan $100 \mathrm{~kg}$ P2O5/ha pada pertumbuhan kedelai, aktivitas fiksasi $\mathrm{N}$, dan serapan $\mathrm{N}$ dan $\mathrm{P}$. Sehingga penggunaan fungi pelarut $\mathrm{P}$ dan mikoriza dapat menghemat 50 persen pemupukan $\mathrm{P}$.

D. Tiens Golden Harvest

Tiens Golden Harvest berbahan akktif Mikroba Indegenous asli Indonesia ramah lingkungan (tidak mengandung logam berat $\mathrm{As}, \mathrm{Pb}, \mathrm{Hg}, \mathrm{Cd}$ dan Mikroba Patogen, Salmonella $\mathrm{Sp}$ ) telah dipersiapkan serta dirancang untuk pembangunan dunia pertanian yang berkelanjutan. Bahwa perpaduan Tiens Golden Harvest dengan pupuk kimia aka selalu dicari dan dibutuhkan petani karena sudah terbukti dan teruji (menjadikan produktivitas tinggi dan ramah lingkungan).

Kandungan Tiens Golden Harvest. Azobacter sp2. Mikroba pelarut fosfat3. Azospirilum sp . Mikroba Pendegradasi Selulose. Lactobacillussp. Pseudomonas $\mathrm{spp}=$ $34,70 \mathrm{ppm} ; \mathrm{K}=1700 \mathrm{ppm} ; \mathrm{C}$ organik $=0,92 \% ; \mathrm{N}=0,04 \% ; \mathrm{Fe}=44,3 \mathrm{ppm} ; \mathrm{Mn}=0,23$ 
Jurnal Media Pertanian Vol. 2 No. 1 Tahun 2017 Hal. 24 - 36

Media Komunikasi Hasil Penelitian dan Review Literatur Bidang Ilmu Agronomi ISSN $2503-1279$

ppm ; $\mathrm{Cu}=0,85 \mathrm{ppm} ; \mathrm{Zn}=3,7$ ppm Tiens Golden Harvest adalah sebuah Teknologi modern sebagai Pupuk penyubur tanah dan tanaman. Dengan menggunakan pupuk hayati Tiens Golden Harvest yang dibuat dengan teknologi Agricultural Growth Promoting Inoculant (AGPI), suatu inokulan campuran yang berbentuk cair, mengandung hormon tumbuh indole acetic acid serta mikroba indigenous (mikroba tanah setempat) asli indonesia, yang sangat dibutuhkan dalam proses penyuburan tanah secara biologi antara lain Azospirillum, Azotobacter, mikroba pelarut P, Lactobacillus, dan mikroba pendegrasi selulosa. Mikroba dan enzim tersebut dapat bekerja secara maksimal dan dapat mengubah unsur hara yang tadinya sulit untuk diserap tanaman menjadi unsur hara yang mudah diserap oleh tanaman sehingga penggunaan pupuk menjadi sangat efisien. Teknologi ini adalah asli Indonesia yang merupakan hasil riset mempunyai tujuan untuk meringankan beban petani dengan masalah biaya produksi pertanian sekarang ini sangatlah mahal. Produk ini Sudah teruji Dan terbukti mampu menghemat biaya produksi pertanian sampai $40 \%$ dan sanggup meningkatkan produksi atau hasil pertanian antara $15 \%$ hingga $70 \%$.

E. Migro Plus

Teknologi yang digunakan adalah generasi terbaru, yaitu menggunakan Mikroba strain terbaru yang bekerja lebih efektif dan efisien. Produk-produk yang menggunakan teknologi terbaru ini adalah produk yang diproduksi oleh MiG corp. yaitu : pupuk hayati Migro Plus, probiotik MiG ternak, Migro Tambak dan probiotik Migro Suplemen. Menggunakan mikroorganisme dengan strain terbaru. Proses produksi dengan kontrol kualitas yang sangat ketat oleh orang-orang yang ahli pada bidangnya. Bahan baku yang digunakan sudah memiliki sertifikat dari sucofindo.

Kemasan yang digunakan eksklusif (tidak ada di pasaran), sehingga keaslian produk MiG corp. sampai ke tangan konsumen lebih terjamin. Hormon tumbuh Indole Acetic Acid serta mikroba indegenous (mikroba tanah setempat) asli indonesia, yang sangat dibutuhkan dalam proses penyuburan tanah secara biologi antara lain Azospirillum sp, Azotobacter sp, mikroba pelarut $\mathrm{P}$, Lactobacillus sp, dan mikroba pendegradasi selulosa serta Pseudomonas sp.

Hormon tumbuh berfungsi untuk memacu pertumbuhan akar serabut sehingga penyerapan hara menjadi optimal, penambat Nitrogen dari udara, melepaskan $\mathrm{P}$ yang terikat di dalam tanah, dan menguraikan bahan organik yang terdapat di tanah, juga terdapat mikroba Pseudomonas sp, yang berfungsi untuk menguraikan residu pestisida yang jatuh di tanah. Apabila setiap aplikasi kurang dari 2 liter Migro Plus per hektar, populasi mikroba untuk menambatkan $\mathrm{N}$, pelarut $\mathrm{P}$ dan pendegradasi selulosa tidak cukup untuk mengambil unsur-unsur tadi atau dengan kata lain, unsur $\mathrm{N}, \mathrm{P}$ dan $\mathrm{K}$ tidak dapat diambil dengan jumlah yang seharusnya dapat diambil oleh mikroorganisme tersebut, sehingga kebutuhan hara oleh tanaman menjadi tidak terpenuhi Karena pada tanaman padi terdapat fase pertumbuhan, pembentukan anakan dan primordial, dimana pada fase tersebut tanaman membutuhkan hara yang cukup untuk tumbuh kembangnya, apabila pada fase tersebut tanaman kurang mendapat pasokan hara, dipastikan hasil yang akan diperoleh dari tanaman tersebut akan kurang baik.

Mikroba yang terdapat dalam Migro Plus, ada yang berfungsi sebagai penambat N, mikroba inilah yang akan menambatkan $\mathrm{N}$ dari udara. Kemudian terdapat juga bakteri 
Jurnal Media Pertanian Vol. 2 No. 1 Tahun 2017 Hal. 24 - 36

Media Komunikasi Hasil Penelitian dan Review Literatur Bidang Ilmu Agronomi ISSN $2503-1279$

selulolitik, bakteri ini berfungsi mendegradasi selulosa yang berasal dari jerami, daun-daun atau bahan-bahan organik lain. Hasil dari pendegradasian tersebut, akan mendapatkan $\mathrm{K}$ dan unsur lain.

Kandungan $\mathrm{P}$ di tanah Indonesia menurut hasil penelitian para ahli tanah adalah masih banyak atau jenuh karena unsur tersebut masih terikat oleh mineral liat tanah, jadi tidak dapat termanfaatkan langsung oleh tanaman. Disinilah fungsi dari mikroba pelarut $\mathrm{P}$ tersebut, karena mikroba tersebut akan melarutkan/melepaskan ikatan Phosphat dalam mineral liat tanah, sehingga unsur $\mathrm{P}$ dapat dimanfaatkan oleh tanaman. Penggunaannya adalah disemprotkan pada tanah atau media tanam lainya atau disiramkan disekitar akar tanaman dengan dosis tertentu, dosis yang dianjurkan adalah $10 \mathrm{ml}$ pupuk hayati Migro Plus dengan maksimum 2 liter air. Tidak masalah, apabila dosis yang diberikan terlalu banyak tidak akan membuat tanaman itu sakit, rusak atau mati. Malahan tanaman menjadi semakin subur (Madjid, 2009).

\section{KESIMPULAN}

Mikroba yang berperan sebagai pelarut hara adalah bakteri pelarut fosfat dan mikoriza masing-masing berperan sebagai pelarut unsur hara P. Inokulan mikroba ini dikembangkan sebagai pupuk hayati yang diaplikasikan langsung ke lahan pertanian dapat memperbaiki kesuburan tanah dan meningkatkan produksi pertanian.

Bentuk-bentuk inokulan pupuk mikroba adalah biakan agar, biakan cair, biakan kering, biakan kering beku, dan tepung. Inokulan yang sering digunakan adalah yang berbentuk biakan cair dan tepung. Bahan pembawa (carrier) yang diperlukan inokulan tepung, dapat digunakan bahan organik seperti gambut, arang, sekam, dan kompos. Untuk bahan pembawa anorganik digunakan bentonit, vermikulit, atau zeolit.

Produk pupuk hayati pelarut hara yang telah dihasilkan ; Pupuk Hayati Enchancing Microbial Activities in The Soils, Bio-Lestari, Tiens Golden Harvest, Migra Plus dan Pupuk Hayati Bio-fosfat.

\section{DAFTAR PUSTAKA}

Elfiati, D. 2005. Peranan Mikroba Pelarut P terhadap Pertumbuhan Tanaman. Tesis. Fakultas Pertanian USU. Medan

Gunalan, 2006. Penggunaan Mikroba Bermanfaat pada Bioteknologi Tanah Berwawasan Lingkungan. Majalah Sriwijaya.Universitas Sriwijaya. 32(2).

Hasanudin. 2003. Peningkatan Kesuburan Tanah dan Hasil Kedelai akibat inokulasi Mikroba Pelarut Fospat dan Azotobacter pada Ultisol. Tesis. Faperta Universitas Bengkulu.

Handayanto, E. dan Hairiyah, K. 2007. Biologi Tanah Landasan Pengelolaan Tanah Sehat. Edisi 1. Pustaka Adipura.

Kartika.E. 2006. Tanggap pertumbuhan, serapan hara dan karakter morfofisiologi terhadap cekaman kekeringan pada bibit kelapa sawit yang bersimbiosis dengan CMA. Disertasi. Sekolah Pascasarjana Institut Pertanian Bogor. 
Jurnal Media Pertanian Vol. 2 No. 1 Tahun 2017 Hal. 24 - 36

Media Komunikasi Hasil Penelitian dan Review Literatur Bidang Ilmu Agronomi ISSN $2503-1279$

Madjid, A. 2009. Dasar Ilmu Tanah. Bahan Ajar Online. Fakultas Pertanian Unsri \& Program Studi Ilmu Tanaman, Program Magister, Program Pascasarjana, Universitas Sriwijaya. http://dasar2ilmutanah.blogspot.com.

Rao, N.S.S. 2004. Soil Microorganisms and Plant Growth. Oxford and IBM Publishing Co. (Terjemahan Susilo.H. Mikroorganisme Tanah dan Pertumbuhan Tanaman. UI Press).

Rahmawati, N. 2005. Pemanfaatan Biofertilizer pada Pertanian Organik. Tesis. Universitas Sumatera Utara Medan.

Yuwono, N.W. 2008. Pupuk Hayati . Penerbit Universitas Gajah Mada. Edisi 1. Yogyakarta. 